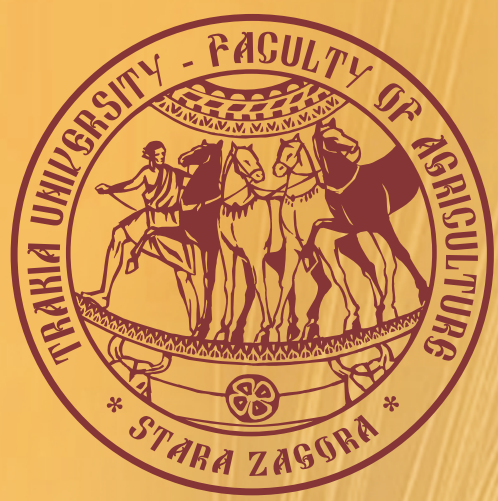

ISSN $1313-8820$ (print)

ISSN 1314 - 412X (online)

Volume 9 , Number 4

December 2017

\title{
AGRICULTURAL
}

\section{SCIENCE AND TECHNOLOGY}

\section{7}

An International Journal Published by Faculty of Agriculture, Trakia University, Stara Zagora, Bulgaria 


\section{Editor-in-Chief}

Georgi Petkov

Faculty of Agriculture

Trakia University, Stara Zagora

Bulgaria

E-mail: gpetkov@af.uni.sz.bg

\section{Co-Editor-in-Chief}

Dimitar Panayotov

Faculty of Agriculture

Trakia University, Stara Zagora

Bulgaria

\section{Editors and Sections}

\section{Genetics and Breeding}

Tsanko Yablanski (Bulgaria)

Atanas Atanasov (Bulgaria)

Svetlana Georgieva (Bulgaria)

Nikolay Tsenov (Bulgaria)

Max Rothschild (USA)

Ihsan Soysal (Turkey)

Horia Grosu (Romania)

Stoicho Metodiev (Bulgaria)

Bojin Bojinov (Bulgaria)

\section{Nutrition and Physiology}

Nikolai Todorov (Bulgaria)

Peter Surai (UK)

Ivan Varlyakov (Bulgaria)

George Zervas (Greece)

Vasil Pirgozliev (UK)

\section{Production Systems}

Radoslav Slavov (Bulgaria)

Dimitar Pavlov (Bulgaria)

Bogdan Szostak (Poland)

Banko Banev (Bulgaria)

Georgy Zhelyazkov (Bulgaria)

\section{Agriculture and Environment}

Martin Banov (Bulgaria)

Peter Cornish (Australia)

Vladislav Popov (Bulgaria)

Tarek Moussa (Egypt)

\section{Product Quality and Safety}

Stefan Denev (Bulgaria)

Vasil Atanasov (Bulgaria)

Roumiana Tsenkova (Japan)

\section{English Editor}

Yanka Ivanova (Bulgaria)
Scope and policy of the journal

Agricultural Science and Technology /AST/

- an International Scientific Journal of Agricultural and Technology Sciences is published in English in one volume of 4 issues per year, as a printed journal and in electronic form. The policy of the journal is to publish original papers, reviews and short communications covering the aspects of agriculture related with life sciences and modern technologies. It will offer opportunities to address the global needs relating to food and environment, health, exploit the technology to provide innovative products and sustainable development. Papers will be considered in aspects of both fundamental and applied science in the areas of Genetics and Breeding, Nutrition and Physiology, Production Systems, Agriculture and Environment and Product Quality and Safety. Other categories closely related to the above topics could be considered by the editors. The detailed information of the journal is available at the website. Proceedings of scientific meetings and conference reports will be considered for special issues.

\section{Submission of Manuscripts}

There are no submission / handling / publication charges.

All manuscripts written in English should be submitted as MS-Word file attachments via e-mail to editoffice@agriscitech.eu. Manuscripts must be prepared strictly in accordance with the detailed instructions for authors at the website

www.agriscitech.eu and the instructions on the last page of the journal. For each manuscript the signatures of all authors are needed confirming their consent to publish it and to nominate on author for correspondence.

They have to be presented by a submission letter signed by all authors. The form of the submission letter is available upon from request from the Technical Assistance or could be downloaded from the website of the journal. Manuscripts submitted to this journal are considered if they have submitted only to it, they have not been published already, nor are they under consideration for publication in press elsewhere. All manuscripts are subject to editorial review and the editors reserve the right to improve style and return the paper for rewriting to the authors, if necessary. The editorial board reserves rights to reject manuscripts based on priorities and space availability in the journal.

The journal is committed to respect high standards of ethics in the editing and reviewing process and malpractice statement. Commitments of authors related to authorship are also very important for a high standard of ethics and publishing. We follow closely the Committee on Publication Ethics (COPE), http://publicationethics.org/resources/guid elines

The articles appearing in this journal are indexed and abstracted in: DOI, EBSCO Publishing Inc., AGRIS (FAO) and DOAJ.

The journal is accepted to be indexed with the support of a project № BG051P00013.3.05-0001 "Science and business" financed by Operational Programme "Human Resources Development" of EU. The title has been suggested to be included in SCOPUS (Elsevier) and Electronic Journals Submission Form (Thomson Reuters).

The journal is freely available without charge to the user or his/her institution. Users can read, download, copy, distribute, print, search, or link to the full texts of the articles, or use them for any other lawful purpose, without asking prior permission from the publisher or the author.

This issue is printed with the financial support by Contract No DNP 0521/20.12.2016, financed from Fund 'Scientific Research' grant Bulgarian scientific Periodicals.

\section{Address of Editorial office:}

Agricultural Science and Technology Faculty of Agriculture, Trakia University

Student's campus, 6000 Stara Zagora

Bulgaria

Telephone: +35942699330 $+35942699446$

www.agriscitech.eu

Technical Assistance:

Nely Tsvetanova

Telephone: +359 42699446

E-mail:editoffice@agriscitech.eu 


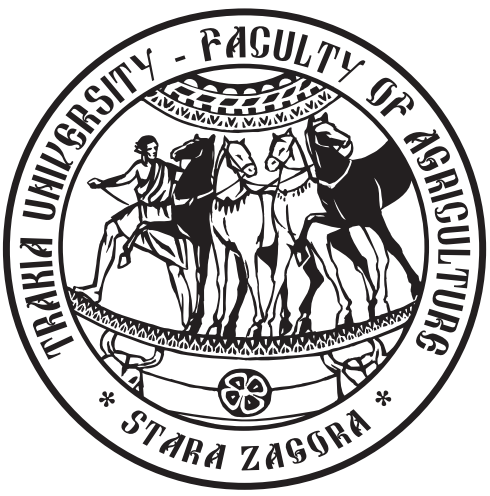

AGRICULTURAL

SCIENCE AND TECHNOLOGY

\section{7}

An International Journal Published by Faculty of Agriculture,

Trakia University, Stara Zagora, Bulgaria 


\title{
Productivity of durum wheat cultivar Predel at nitrogen-phosphorous fertilization
}

\author{
L. Plescuta* \\ Department of Plant Production, Faculty of Agriculture, Trakia University, 6000 Stara Zagora, Bulgaria
}

(Manuscript received 30 June 2017; accepted for publication 10 October 2017)

\begin{abstract}
The effect of nitrogen-phosphorus fertilization at nitrogen rates 0, 80,120 and $160 \mathrm{~kg}^{-h a^{-1}}$ and 0,80 and $120 \mathrm{~kg} \cdot \mathrm{ha}^{-1}$ for phosphorus has been studied in durum wheat Predel cultivar, grown on leached vertisol soil type during the period 2012-2014 in the field of the Field Crops Institute - Chirpan. The results show that at alone nitrogen fertilization grain yield reaches 3,75 t. ha ${ }^{-1}$ at moderate $N_{120}$, while at alone phosphorus fertilization the increase compared to the nonfertilized control $\left(2,50\right.$ t.ha $\left.{ }^{-1}\right)$ is insignificant. At combined $N_{120} P_{120}$ the highest grain yield was obtained during the period -4.50 t.ha ${ }^{-1}$, with $57.41 \%$ above the control. The harvest index of durum wheat grain variety Predel is 0.353 on average. Good $H I$ results are formed at fertilization with $P_{120}$ and $N_{80} P_{80}$.
\end{abstract}

Keywords: durum wheat, fertilization, vertisol soil

\section{Introduction}

Optimizing mineral fertilization of agricultural crops is one of the most important agro-technical means for creating a favourable environment for plant development, for providing the needed nutrients and increasing the yield. As a result of the optimal fertilization rate soil fertility improves and sustainable economic growth of farms is achieved (Gerganov, 2009).

The use of nitrogen fertilizers in wheat growing is one of the techniques that influences and strongly affects growth and productivity (Bindrabadan, 1999; Vandeleur et al., 2005; Ruggiero and Angelino, 2007). Protein synthesis in plant tissues is directly dependent on nitrogen fertilization, especially in maize and cereals (Stoyanova and Petkova, 2009).

Durum wheat needs nitrogen throughout its vegetative season. For the formation of $100 \mathrm{~kg}$ of grain under the conditions of Bulgaria, 3.0-3.7 kg N is extracted (Panayotova and Dechev, 2004; Dechev et al., 2010; Almaliev et al., 2014). Nitrogen fertilization should be well balanced with the soil phosphorus and potassium content and provide for the generation of planned high yields, including amounts covering for nitrogen losses due to washing out (Yanev et al., 2006). Kolev (2005) also reports that the main requirement for high yield coupled with good grain quality is for plants to receive the optimal amount of nitrogen during vegetation.

Ercoli and Mariotti (2006) stated that significant differences in yield, dry matter and nitrofen quantity accumulation have been found in experiments with durum wheat varieties in Italy at fertilization with $150 \mathrm{~kg} \mathrm{~N} / \mathrm{ha}, 150 \mathrm{~kg} \mathrm{P}_{2} \mathrm{O}_{5} / \mathrm{ha}$ and $150 \mathrm{~kg} \mathrm{~K}_{2} \mathrm{O}_{5} / \mathrm{ha}$. In the evaluation of grain yields of durum wheat varieties grown at different fertilization rates, Dechev and Panayotova (2010) found that on average for a 11 -year period grain yield was $4267 \mathrm{t}^{-h^{-1}}$, the latter growing from 3189 t.ha ${ }^{-1}$ without fertilization to 4930 t.ha ${ }^{-1}$ at $\mathrm{N}_{160}$.

The objective of the present study is to investigate the effect of nitrogen-phosphorus fertilization on the yield of durum wheat variety Predel at different fertilization rates.

\section{Material and methods}

The study was conducted with durum wheat variety Predel during the period 2012 - 2014 in stationary fertilization experiment with two-field crop rotation of cotton-durum wheat under nonirrigated conditions in the field of the Field Crops Institute (FCI) Chirpan at leached vertisol soil type. The field experiment was carried out by block method with 12 variants at plot size of $10 \mathrm{~m}^{2}$ $(2.40 \times 4.20 \mathrm{~m})$ in 4 replications. For side guards between the fertilized plots concrete slabs were placed and the transverse guard is $1.50 \mathrm{~m}$. The study includes the Bulgarian durum wheat variety Predel, created at Field Crops Institute - Chirpan.

Nitrogen fertilization at rates $\mathrm{N}_{0}, \mathrm{~N}_{80}, \mathrm{~N}_{120}, \mathrm{~N}_{160}$ was applied. With regard to phosphorus, the tested fertilizarion rates are $P_{0}, P_{80}, P_{120}$. The autonomous and complete combined effect of nitrogen and phosphorus has been traced. Nitrogen as ammonium nitrate was applied twice: $1 / 3$ pre-sowing and $2 / 3$ as early spring feeding. Phosphorus as triple superphosphate for durum wheat was applied with the pre-sowing field cultivation. The control is non-fertilized durum wheat.

According to FAO classification the soil in the field of $\mathrm{FCl}$ Chirpan is a leached vertisol (Pellic vertisols) and as a whole it belongs to the most fertile and widespread and significant soils in Bulgaria. It is suitable for growing field crops and has the potential to form high yields. It is distinguished by a powerful humus horizon (70$100 \mathrm{~cm}$ ) and by humus content it refers to the moderate humus soils. The soil reaction is from slightly acid to neutral. The soil in the experimental field has volume weight of $1.15-1.2 \mathrm{~g}_{\mathrm{cm}} \mathrm{cm}^{-3}$ and a relative density of 2.4-2.6. The sorption capacity is high - 35-45 mequ/100 g of soil. The total nitrogen stock in the $0-30 \mathrm{~cm}$ layer is $500-600 \mathrm{~kg} \mathrm{da}^{-1}$. The amount of total phosphorus is $100-250 \mathrm{mg} / 100$ $\mathrm{g}$ of soil. The soil is characterized by high moisture content, due to the high percentage of clay minerals, low water permeability and total porosity, poor to moderate with digestible nitrogen, poor supply of digestible phosphorus and good supply of exchange and reserve 
Table 1. Soil supply with nutrient elements at field experiment with durum wheat

\begin{tabular}{|c|c|c|c|c|c|}
\hline \multirow{2}{*}{ Depth (cm) } & \multicolumn{3}{|c|}{ Mineral nitrogen (mg. $\mathrm{kg}^{-1}$ soil) } & \multirow{2}{*}{$\mathrm{P}_{2} \mathrm{O}_{5}(\mathrm{mg} / 100 \mathrm{~g})$} & \multirow{2}{*}{$\mathrm{K}_{2} \mathrm{O}(\mathrm{mg} / 100 \mathrm{~g})$} \\
\hline & $\mathrm{NH}_{4}-\mathrm{N}$ & $\mathrm{NO}_{3}-\mathrm{N}$ & $\mathrm{N}_{\text {min }}$ & & \\
\hline Avarage $0-20$ & 25.80 & 15.40 & 41.20 & 3.2 & 19.8 \\
\hline Avarage $20-40$ & 20.02 & 10.01 & 30.03 & 2.8 & 17.8 \\
\hline
\end{tabular}

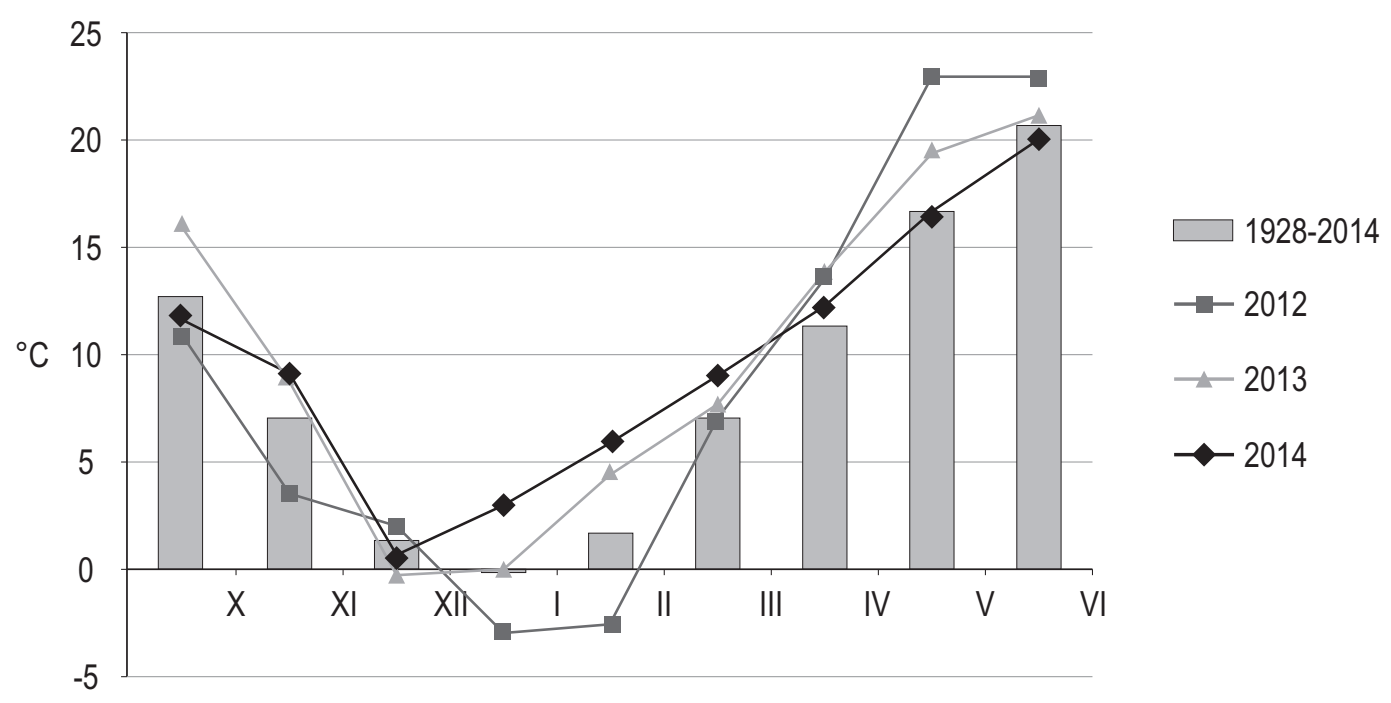

Figure 1. Average diurnal air temperature during the vegetation period of durum wheat (2012-2014)

potassium.

Agrochemical analyses show that the mineral nitrogen content averaged $41.20 \mathrm{mg} \cdot \mathrm{kg}^{-1}$ soil for the $0-20 \mathrm{~cm}$ layer and for the subplough layer $30.03 \mathrm{mg} \cdot \mathrm{kg}^{-1}$ soil. The content of mobile phosphates is low $-3.0-4.4 \mathrm{mg} / 100 \mathrm{~g}$ soil in the $0-20 \mathrm{~cm}$ layer and 2.6 to $3.0 \mathrm{mg} / 100 \mathrm{~g}$ soil for the soil layer $20-40 \mathrm{~cm}$. The soil is well supplied with digestible potassium - an average of $19.8 \mathrm{mg} / 100 \mathrm{~g}$ soil (19.5-20.1 mg/100 $\mathrm{g}$ of soil) in the $0-20 \mathrm{~cm}$ layer and $17.8 \mathrm{mg} / 100 \mathrm{~g}$ of soil for the 20-40 cm layer (Table 1).

The temperature amount during the vegetation period of durum wheat characterizes 2012 as moderately warm, and 2013 and 2014 as very warm (Figure 1).
According to precipitation supply 2012 and 2013 are moderately dry, while 2014 is moist (Figure 2).

\section{Results and discussion}

The results obtained from the survey, averaged for the period 2012 -2014, indicate that mineral fertilization has a very good effect on durum wheat productivity. This has also been found in the studies by Kostadinova and Panayotova (2002) and other authors who also found that the application of nitrogen has strong effect on grain yield from durum wheat. As a result of the natural soil fertility (without

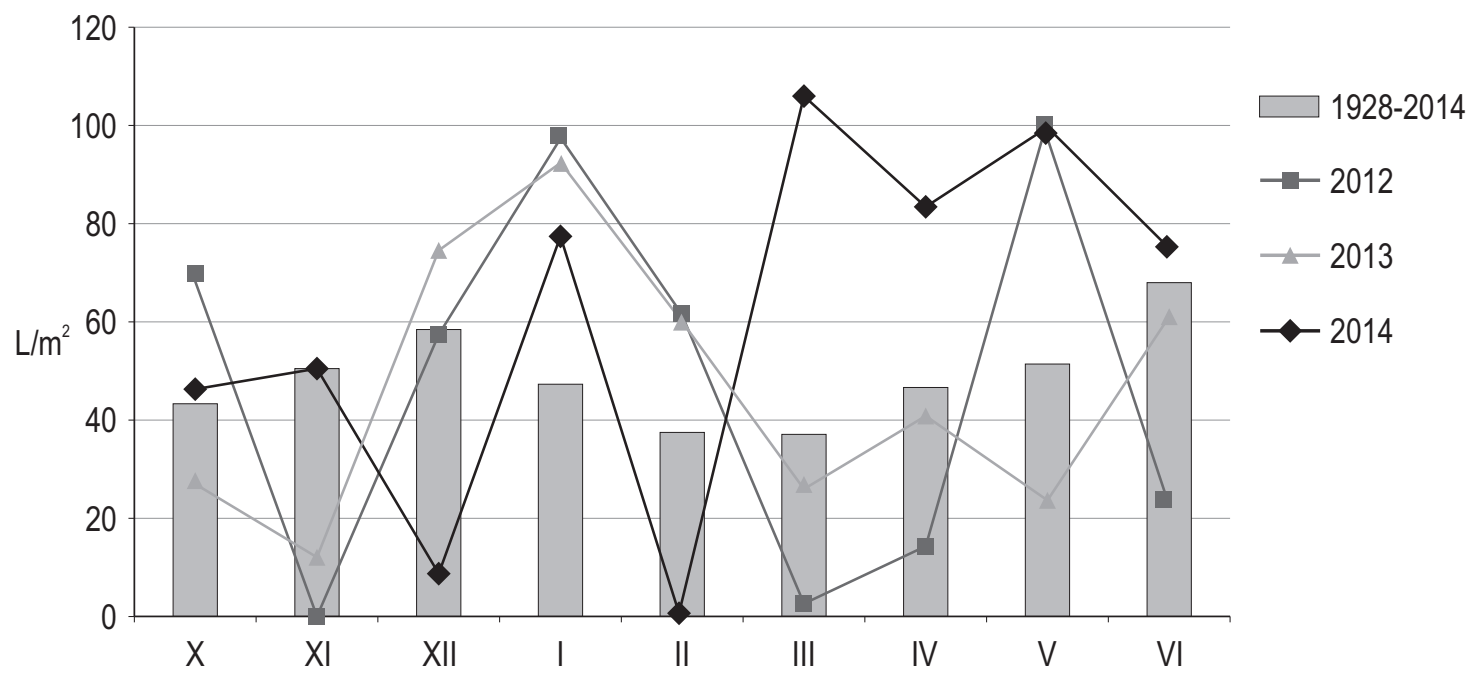

Figure 2. Monthly amount of precipitation during the vegetation period of durum wheat (2012-2014) 
Table 2. Grain yield of durum wheat variety Predel to nitrogen-phosphorous fertilization, 2012-2014 r., t.ha ${ }^{-1}$

\begin{tabular}{|c|c|c|c|c|c|c|c|c|}
\hline \multirow{2}{*}{ Fertilization } & \multicolumn{2}{|c|}{2012} & \multicolumn{2}{|c|}{2013} & \multicolumn{2}{|c|}{2014} & \multicolumn{2}{|c|}{ Average } \\
\hline & t.ha $^{-1}$ & $\%$ & t.ha-1 & $\%$ & t.ha $^{-1}$ & $\%$ & t.ha ${ }^{-1}$ & $\%$ \\
\hline $\mathrm{N}_{0} \mathrm{P}_{0} \mathrm{~K}_{0}$ & 2.62 & 100.0 & 2.16 & 100.0 & 2.74 & 100.0 & 2.50 & 100.0 \\
\hline $\mathrm{N}_{80}$ & 3.48 & 133.1 & 3.48 & 161.2 & 3.23 & 117.9 & $3.40^{* * *}$ & 135.6 \\
\hline $\mathrm{N}_{120}$ & 3.86 & 147.8 & 3.94 & 182.3 & 3.46 & 126.3 & $3.75^{\star \star *}$ & 149.9 \\
\hline $\mathrm{N}_{160}$ & 3.92 & 149.9 & 3.64 & 168.5 & 3.09 & 113.0 & $3.55^{\star * *}$ & 141.8 \\
\hline $\mathrm{P}_{80}$ & 2.80 & 107.1 & 2.19 & 101.7 & 2.80 & 102.2 & 2.60 & 103.7 \\
\hline $\mathrm{N}_{80} \mathrm{P}_{80}$ & 3.80 & 145.3 & 3.57 & 165.2 & 3.68 & 134.5 & $3.68^{* * *}$ & 147.1 \\
\hline $\mathrm{N}_{120} \mathrm{P}_{80}$ & 4.18 & 159.7 & 3.88 & 179.6 & 3.47 & 126.6 & $3.84^{* * *}$ & 153.4 \\
\hline $\mathrm{N}_{160} \mathrm{P}_{80}$ & 4.38 & 167.3 & 3.73 & 172.7 & 3.27 & 119.3 & $3.79^{* * *}$ & 151.4 \\
\hline$P_{120}$ & 2.78 & 106.5 & 2.26 & 104.5 & 2.77 & 101.1 & 2.60 & 104.0 \\
\hline $\mathrm{N}_{80} \mathrm{P}_{120}$ & 3.79 & 144.8 & 3.43 & 158.9 & 3.78 & 138.1 & $3.67^{\star * *}$ & 146.4 \\
\hline $\mathrm{N}_{120} \mathrm{P}_{120}$ & 4.26 & 163.1 & 3.77 & 174.5 & 3.79 & 138.5 & $3.94^{* * *}$ & 157.4 \\
\hline $\mathrm{N}_{160} \mathrm{P}_{120}$ & 4.50 & 172.3 & 3.77 & 174.6 & 3.42 & 124.8 & $3.90^{* * *}$ & 155.6 \\
\hline Average & 3.72 & - & 3.31 & - & 3.29 & - & 3.44 & - \\
\hline$G D_{5 \%}$ & 0.319 & 12.2 & 0.718 & 33.3 & 0.532 & 19.4 & 0.270 & 10.79 \\
\hline$G D_{1 \%}$ & 0.429 & 16.4 & 1.014 & 46.9 & 0.721 & 26.3 & 0.358 & 14.27 \\
\hline$G D_{0,1 \%}$ & 0.567 & 21.7 & 1.448 & 67.1 & 0.965 & 35.2 & 0.461 & 18.42 \\
\hline$V C, \%$ & 5.97 & & 10.24 & & 8.39 & & 5.60 & \\
\hline
\end{tabular}

$* * *$ - significant at $\mathrm{P} \leq 0.001$

fertilization) during the studied period, Predel variety forms an average grain yield of 2.50 tha $^{-1}$, within the following limit during the years from 2.62 to 2.74 t.ha $^{-1}$ (Table 2 ).

Differences in grain yields between the studied nitrogen fertilization rates throughout the period are substantial. The studied alone $\mathrm{N}$ fertilization, which is often applied in cereal crops, shows an increase in average yields up to a rate of $\mathrm{N}_{120}$ - an average of 3.75 t.ha ${ }^{-1}$, with $49.87 \%$ above the untreated control. The high nitrogen fertilization rate $\mathrm{N}_{160}$ reduces the yield by $8.11 \%$ compared to the moderate level of $N_{120}$. Very good were the results throughout the period when applying test rate of $\mathrm{N}_{80}-3.40$ t.ha ${ }^{-1}$, exceeding the control by 0.89 t.ha ${ }^{-1}$ or $35.6 \%$.

A number of authors (Giorgio et al., 1992; Kostadinova and Panayotova, 2003) point out that the effect of higher nitrogen rates is more pronounced during meteorologically favourable years, well supplied with precipitation. In the present study, the favorable 2013 was characterized by the highest grain yield obtained at nitrogen rate of $120 \mathrm{~kg} \cdot \mathrm{ha}^{-1}-3.94$ t.ha ${ }^{-1}$, proven to exceed the other fertilization rates. The difference between the yield obtained from the natural soil stock and that of the fertilizer plants with 0;80;120 and $160 \mathrm{~kg} \mathrm{~N}$.ha ${ }^{-1}$ is $1.32 ; 1.78$ and 1.48 t.ha $^{-1}$, respectively, more in the case of nitrogen fertilization.

Fertilization with the high phosphorus rate of $P_{120}$ during the studied period showed an insignificant increase in grain yield compared to the non-fertilized control and in the harvest 2012 the yield reached a maximum of 2.78 t.ha ${ }^{-1}, 6.5 \%$ above the control. On average for the period at that rate grain yield is 2.60 t.ha $^{-1}$. At the low phosphorus rate $P_{80}$ yield increases insignificantly and in 2012 and 2014 it is 2.80 t.ha $^{-1}$, which is $10.7 \%$ for 2012 and $10.2 \%$ for 2014 above non-fertilized.

Combined fertilization with increasing nitrogen and phosphorus rates results in increased grain yields in Predel variety. In fertilization with the highest nitrogen-phosphorus rate $\mathrm{N}_{160} \mathrm{P}_{120}$ the highest yield is obtained -4.50 t.ha $^{-1}$. Compared to the non-fertilized variant, the relative yield increase at $\mathrm{N}_{160} \mathrm{P}_{120}$ in 2013 was $74.6 \%$ above the control, and the average for the studied period $-55.6 \%$ more.

The dispersion analysis for grain yield in the study shows that the differences between the factors - nitrogen rates, phosphorus rates and years are significant (Table 3). With the independent action of the factors, the nitrogen fertilization rate is the strongest source of variation $(14.02 \%$ of total effect), proven at $p \leq 0.001$. The conditions over the years also have high impact $(9.99 \%)$. The effect of phosphorous nutrition is insignificant $(0.22 \%)$, i.e. the applied phosphorus rates have one-way effect. The interaction of $\mathrm{N} x \mathrm{P}$ is very strong $(54.51 \%)$, which statistically indicates that grain yield increases by combined fertilization with increasing nitrogen and phosphorus rates. Insignificant is the interaction $\mathrm{P} x$ Year, and $\mathrm{N} \mathrm{x}$ Year is proven at $p \leq 0.01$.

Concerning the independent action of nitrogen (Figure 3), it was found on average for the experiment that the high $\mathrm{N}_{160}$ rate stimulated the formation of the highest yield - 3.84 t.ha $^{-1}$, followed by $\mathrm{N}_{120}-3.41$ t.ha' ${ }^{-1}$.

The best effect on yield had the main action of phosphorus rate $P_{120}$, but the differences with the effect of the other tested phosphorus rates were insignificant (Figure 4).

The harvest index $(\mathrm{HI})$ is an important factor for effective plant production (Swaider et al., 1994; Parry and Reynolds, 2007). For the trial period, the average harvest index is good -0.353 , the highest harvest index being in $2014-0.356$, with lower values in $2012-0.353$ (Table 4). With the non-fertilized control, the harvest index for the period is 0.359 on average. The application of the low nitrogen rate $\mathrm{N}_{80}$ results in unproved increase by $0.56 \%$ compared to nonfertilized. At moderate and high nitrogen rate $\left(\mathrm{N}_{120}\right.$ and $\left.\mathrm{N}_{160}\right)$, the harvest index of the yield for variety Predel decreases compared to the control by 2.51 and $5.57 \%$, respectively. With $\mathrm{N}_{160}$ fertilization in 2014 , the lowest value was recorded - 0.326. In combined 
Table 3. Analysis of variance for grain yield of durum wheat at fertilization, 2012-2014

\begin{tabular}{|c|c|c|c|c|c|}
\hline Source of variation & d.f. & SS & MS, $\%$ & $S$ & $\mathrm{~F}$ \\
\hline Total & 143 & 572124 & 100.00 & & \\
\hline Bloks & 3 & 11364 & $1.99^{* * *}$ & 3788 & 10.20 \\
\hline Variants & 35 & 521768 & $91.20^{* * *}$ & 14908 & 40.14 \\
\hline$A-N$ rate & 3 & 80222 & $14.02^{* * *}$ & 26741 & 72.01 \\
\hline$B$ - $P$ rate & 2 & 1240 & $0.22^{n . s}$ & 620 & 1.67 \\
\hline C-Year & 2 & 57128 & $9.99^{* * *}$ & 28564 & 76.92 \\
\hline$A \times B$ & 6 & 311870 & $54.51^{* * *}$ & 51978 & 139.97 \\
\hline$A \times C$ & 6 & 9098 & $1.59^{\star *}$ & 1516 & 4.08 \\
\hline$B \times C$ & 4 & 396 & $0.07^{\text {n.s }}$ & 99 & 0.27 \\
\hline$A \times B \times C$ & 12 & 61814 & $10.80^{* * *}$ & 5151 & 13.87 \\
\hline Error & 105 & 38992 & 6.81 & 371 & \\
\hline
\end{tabular}

$* * * ; * *$ - significant at $\mathrm{P} \leq 0.001$ and $\mathrm{P} \leq 0.01$, respectively

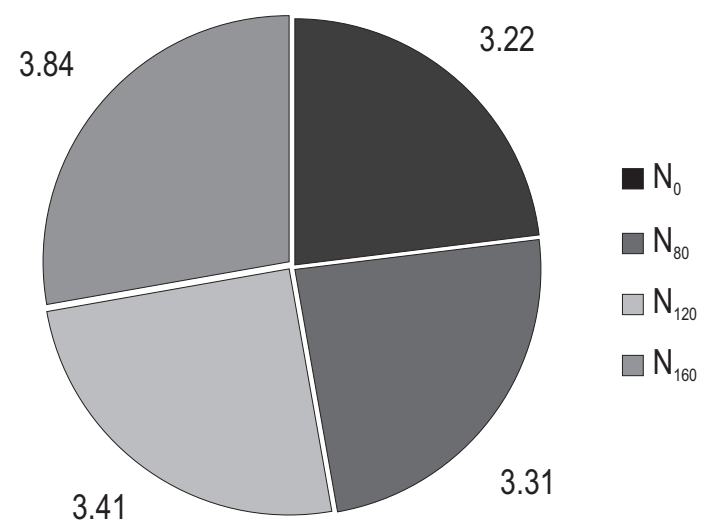

Figure 3. Main effect of nitrogen on grain yield of durum wheat, $t$ /ha

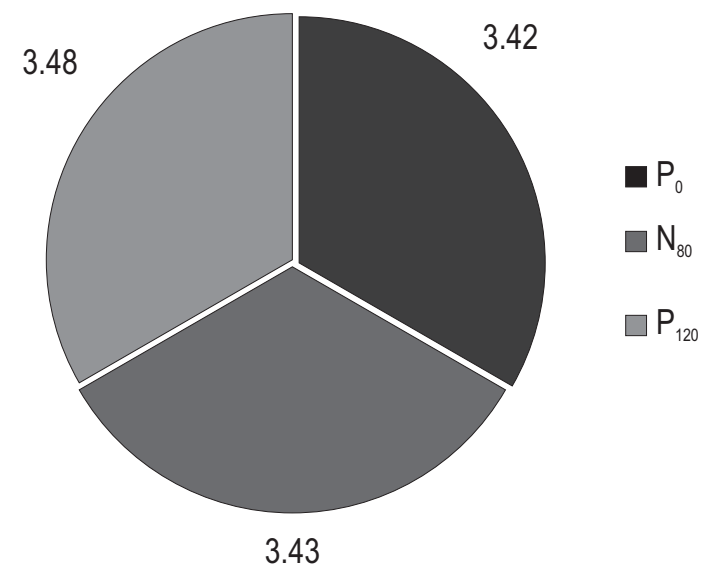

Figure 4. Main effect of phosphorus on grain yield of durum wheat, t/ha

Table 4. Harvest index (HI) of grain yield from durum wheat variety Predel at mineral fertilization, 2012-2014, \%

\begin{tabular}{|c|c|c|c|c|c|c|c|c|}
\hline \multirow{2}{*}{ Fertilization } & \multicolumn{2}{|c|}{2012} & \multicolumn{2}{|c|}{2013} & \multicolumn{2}{|c|}{2014} & \multicolumn{2}{|c|}{ Average } \\
\hline & $\mathrm{HI}$ & $\%$ & $\mathrm{HI}$ & $\%$ & $\mathrm{HI}$ & $\%$ & $\mathrm{HI}$ & $\%$ \\
\hline $\mathrm{N}_{0} \mathrm{P}_{0} \mathrm{~K}_{0}$ & 0.353 & 100.0 & 0.370 & 100.0 & 0.353 & 100.0 & 0.359 & 100.0 \\
\hline $\mathrm{N}_{80}$ & 0.362 & 102.6 & 0.360 & 97.3 & 0.361 & 102.3 & 0.361 & 100.56 \\
\hline $\mathrm{N}_{120}$ & 0.351 & 99.4 & 0.358 & 96.8 & 0.340 & 96.3 & 0.350 & 97.49 \\
\hline $\mathrm{N}_{160}$ & 0.346 & 98.0 & 0.340 & 91.9 & 0.326 & 92.4 & 0.339 & 94.43 \\
\hline $\mathrm{P}_{80}$ & 0.341 & 96.6 & 0.364 & 98.4 & 0.361 & 102.3 & 0.354 & 98.61 \\
\hline $\mathrm{N}_{80} \mathrm{P}_{80}$ & 0.369 & 104.5 & 0.365 & 98.6 & 0.382 & 108.2 & 0.372 & 103.62 \\
\hline $\mathrm{N}_{120} \mathrm{P}_{80}$ & 0.346 & 98.0 & 0.354 & 95.7 & 0.359 & 101.7 & 0.353 & 98.33 \\
\hline $\mathrm{N}_{160} \mathrm{P}_{80}$ & 0.352 & 99.7 & 0.347 & 93.8 & 0.331 & 93.8 & 0.343 & 95.54 \\
\hline$P_{120}$ & 0.353 & 100.0 & 0.355 & 95.9 & 0.368 & 104.2 & 0.359 & 100.00 \\
\hline $\mathrm{N}_{80} \mathrm{P}_{120}$ & 0.353 & 100.0 & 0.348 & 94.0 & 0.361 & 102.3 & 0.354 & 98.61 \\
\hline $\mathrm{N}_{120} \mathrm{P}_{120}$ & 0.351 & 99.4 & 0.358 & 96.8 & 0.350 & 99.2 & 0.353 & 98.33 \\
\hline $\mathrm{N}_{160} \mathrm{P}_{120}$ & 0.357 & 101.1 & 0.343 & 92.7 & 0.354 & 100.3 & 0.351 & 97.77 \\
\hline Average & 0.353 & - & 0.355 & - & 0.356 & - & 0.353 & - \\
\hline \multicolumn{9}{|c|}{ GD $5 \% ; 1 \% ; 0,1 \%=1.49 ; 2.02 ; 2.72$} \\
\hline \multicolumn{9}{|l|}{$V C, \%=2.48$} \\
\hline
\end{tabular}


fertilization with the participation of the high nitrogen rates during the analysed years $\mathrm{HI}$ decreases due to formed larger vegetative mass. Good $\mathrm{HI}$ results are achieved in fertilization with $\mathrm{P}_{120}$ and $\mathrm{N}_{80} \mathrm{P}_{80}$.

\section{Conclusion}

At moderate nitrogen fertilization $\mathrm{N}_{120}$ grain yield of durum wheat variety Predel grows to a maximum degree, an average of 3.75 t.ha ${ }^{-1}$. At combined fertilization with rate $\mathrm{N}_{120} \mathrm{P}_{120}$ the highest grain yield was obtained during the trial period -4.50 t.ha $^{-1}$. Higher yield from the interaction was received in the first year. Independent phosphorus fertilization at moderate and high rates is not an efficient agronomic activity. The harvest index of durum wheat grain variety Predel is 0.353 on average. The greatest effect of all studied factors has the interaction N x P - 48.79\%. In combined fertilization with the participation of the high nitrogen rates during the studied years $\mathrm{HI}$ decreases due to the formed larger vegetative mass. Good HI results are formed at fertilization with $\mathrm{P}_{120}$ and $\mathrm{N}_{80} \mathrm{P}_{80}$.

\section{References}

Almaliev M, Panayotova G, Kostadinova S, 2014. Uptake and utilization efficiency of nitrogen and phosphorus in durum wheat. Book of proceedings Fifth International Scientific Agricultural Symposium „AgroSym 2014“, Jahorina, Bosnia and Herzegovina, October 23-26, 2014, pp. 118-122.

Bindrabadan PS, 1999. Impact of canopy nitrogen profile in wheat on growth. Field Crop Res.earch, 63, 63-77.

Dechev V and Panayotova G, 2010. Assessment of durum wheat varieties grain yield grown under different year conditions and fertilization levels. Plant Science, 47, 23-28.

Dechev D, Bozhanova V, Yanev S, Delchev G, Panayotova G, Saldzhiev I, Nedyalkova S, Hadzhiivanova B and Taneva K, 2010. Achievements and problems in the selection and technology of durum wheat. Field Crops Studies, VI-2, 201-215(Bg).

Ercoli L and Mariotti M, 2006. Grain yield, and dry matter and nitrogen accumulation and remobilization in durumwheat as affected by variety and seeding rate. European Journal of Agronimy, 25, 309-318.
Gerganov D, 2009. Practical and economic problems in the implementation of agri-environment activities in the plant. Almanac, (Research), p. 65.

Giorgio D, Rizzo V and Rinaldi M, 1992. Growth analysis of durum wheat applied to different nitrogen fertilizing doses. Ann. Ist. Sper. Agron., 23, 46.

Kolev T, 2005. Influence of the mineral fertilization and the sowing rate on the productivity of durum wheat variety Saturn 1 . Sb. Reports Balkan Scientific Conference, June 2, 2005, Karnobat, 2, pp. 448450.

Kostadinova S and Panayotova G, 2002. Energetical efficiency of durum wheat fertilization. Bulgarian Journal of Agricultural Science, $\mathrm{VL}, 8,555-560$.

Kostadinova S and Panayotova G, 2003. Agronomic efficiency of nitrogen fertilization of Bulgarian cotton cultivars. Ecology and Future, II, 43-46.

Panayotova $\mathbf{G}$ and Dechev D, 2004. Nitrogen Accumulation and Use in Durum Wheat (Triticum durum Desf.) as Influence by Fertilization. III Internat. Eco-conference on Safe Food, Novi Sad (Serbia and Montenegro), 22-25 September 2004, pp. 263-267.

Parry M and Reynolds M, 2007. Improving resource use efficiency. Annals of Applied Biology, 151, 133-135.

Ruggiero C, Angelino G, 2007. Changes of root hydraulic conductivity and root/shoot ratio of durum wheat and barley in relation to nitrogen availability and mercury exposure. Ital. J. Agron. 3, 281-290.

Sowers KE, Pan WL, Miller BC, Smith JL and Martin E, 2000. Durum grain quality as affected by $\mathrm{N}$-fertilizer near anthesis and irrigation during grain fill. Agronomic. Journal, 92, 1035-1041.

Stoyanova A and Petkova R, 2009. Crude protein content in corn for grain. Collection of Scientific Papers at International Scientific Conference, 4-5 June, Stara Zagora, Technological Issues in Plant Breeding, 2, pp. 1-5.

Swaider J, Chyan Y and Freji, 1994. Genetic aspects of plant mineral nutrition. Journal Plant Nutrition, 17, 1687-1699.

Vandeleur R, Niemietz C, Tilbrook J and Tyerman S, 2005. Roles of aquaporins in root responses to irrigation. Plant Soil, 274, 141146.

Yanev SH, Dechev D, Lalev T, Saldjiev I, Panayotova G, Bojanova B, Delchev G and Nikolov D, 2006. The contribution of the selection and the technology for increasing the productivity and quality of the durum wheat. Field Crops Studies, II-1,11-24. 


\section{Genetics and Breeding}

Variation in the agronomic and morphological traits in spring barley

N. Dyulgerov, B. Dyulgerova

Study on the loss of accuracy of AC method for milk yield control in sheep

D. Dimov, P. Zhelyazkova, A. Vuchkov

Hordein polymorphism between spring barley cultivars by SDS-PAGE electrophoresis

N. Neykov, S. Doneva

\section{Nutrition and Physiology}

Comparative study of rapeseed, monofloral types and multifloral honey by some physico-chemical parameters

I. Zhelyazkova, S. Lazarov

Body condition score, nonesterified fatty acids and beta-hydroxybutyrate concentrations in goats with subclinical ketosis

V. Marutsova, R. Binev

\section{Production Systems}

Lucrative status of improved dual purpose cowpea (Vigna unguiculata L., Walp) in Damboa, Borno State, North-Eastern Nigeria

B.H. Gabdo

Study on the emptying time of grain harvester hoppers

K. Trendafilov, N. Delchev, B. Kolev, G. Tihanov

Length of the growing season and yield in Triticum monococcum L., in accordance with the growing conditions

S. Stamatov, E. Valchinova, G. Desheva, K. Uzundzhalieva, P. Chavdarov, T. Cholakov, B. Kyosev, R.

Ruseva, N. Velcheva

Productivity of durum wheat cultivar Predel at nitrogen-phosphorous fertilization

L. Plescuta

Effect of the herbicide treatment dose on the weed infestation in common winter wheat

Z. Petrova

Evaluation of some technological properties of Caucasian ram wool

D. Pamukova, G. Staykova, N. Stancheva, D. Panayotov 


\section{Agriculture and Environment}

Saved $\mathrm{CO}_{2}$ emissions by using renewable sources for hot water yield in Bulgarian dairy farms

R. Georgiev, R. Slavov, K. Peychev, D. Georgiev, S. Apostolov, J. Ellingsen, J. Tønnesen

Inventory of the legal base for reclamation of lands disturbed by open-cast mining in Bulgaria

M. Banov, V. Tzolova, I. Kirilov

Taxonomic composition of phytoplankton in Black Sea area in front of the Cape Galata (2008-2016)

D. Klisarova, D. Gerdzhikov

Biodiversity of the macrozoobenthos in some protected marine areas along Bulgarian Black Sea coast

E. Petrova, S. Stoykov

Heavy metals in organs of gudgeon (Gobio gobio L.) from Vardar River, R. Macedonia

R. Nastova, V. Kostov, I. Uslinovska

Product Quality and Safety

Mathematical methods for assessment and analysis of honey yield data for Bulgaria and the

N. Keranova

Carcass traits and meat quality of different slow growing and fast growing broiler chickens

M. Oblakova, N. Mincheva, P. Hristakieva, I. Ivanova, M. Lalev, Sv. Georgieva

Role and importance of the awareness for whey in dairy sector at an international level 


\section{Instruction for authors}

\section{Preparation of papers}

Papers shall be submitted at the editorial office typed on standard typing pages (A4, 30 lines per page, 62 characters per line). The editors recommend up to 15 pages for full research paper ( including abstract references, tables, figures and other appendices)

The manuscript should be structured as follows: Title, Names of authors and affiliation address, Abstract, List of keywords, Introduction, Material and methods, Results, Discussion, Conclusion, Acknowledgements (if any), References, Tables, Figures.

The title needs to be as concise and informative about the nature of research. It should be written with small letter /bold, 14/ without any abbreviations.

Names and affiliation of authors The names of the authors should be presented from the initials of first names followed by the family names. The complete address and name of the institution should be stated next. The affiliation of authors are designated by different signs. For the author who is going to be corresponding by the editorial board and readers, an E-mail address and telephone number should be presented as footnote on the first page. Corresponding author is indicated with *

Abstract should be not more than 350 words. It should be clearly stated what new findings have been made in the course of research. Abbreviations and references to authors are inadmissible in the summary. It should be understandable without having read the paper and should be in one paragraph.

Keywords: Up to maximum of 5 keywords should be selected not repeating the title but giving the essence of study.

The introduction must answer the following questions: What is known and what is new on the studied issue? What necessitated the research problem, described in the paper? What is your hypothesis and goal?

Material and methods: The objects of research, organization of experiments, chemical analyses, statistical and other methods and conditions applied for the experiments should be described in detail. A criterion of sufficient information is to be possible for others to repeat the experiment in order to verify results.

Results are presented in understandable tables and figures, accompanied by the statistical parameters needed for the evaluation. Data from tables and figures should not be repeated in the text. Tables should be as simple and as few as possible. Each table should have its own explanatory title and to be typed on a separate page. They should be outside the main body of the text and an indication should be given where it should be inserted.

Figures should be sharp with good contrast and rendition. Graphic materials should be preferred. Photographs to be appropriate for printing. Illustrations are supplied in colour as an exception after special agreement with the editorial board and possible payment of extra costs. The figures are to be each in a single file and their location should be given within the text.

Discussion: The objective of this section is to indicate the scientific significance of the study. By comparing the results and conclusions of other scientists the contribution of the study for expanding or modifying existing knowledge is pointed out clearly and convincingly to the reader. Conclusion: The most important consequences for the science and practice resulting from the conducted research should be summarized in a few sentences. The conclusions shouldn't be numbered and no new paragraphs be used. Contributions are the core of conclusions. References:

In the text, references should be cited as follows: single author: Sandberg (2002); two authors: Andersson and Georges (2004); more than two authors: Andersson et al.(2003). When several references are cited simultaneously, they should be ranked by chronological order e.g.: (Sandberg, 2002; Andersson et al., 2003; Andersson and Georges, 2004).

References are arranged alphabetically by the name of the first author. If an author is cited more than once, first his individual publications are given ranked by year, then come publications with one co-author, two co-authors, etc. The names of authors, article and journal titles in the Cyrillic or alphabet different from Latin, should be transliterated into Latin and article titles should be translated into English. The original language of articles and books translated into English is indicated in parenthesis after the bibliographic reference $($ Bulgarian $=\mathrm{Bg}$, Russian $=\mathrm{Ru}$, Serbian $=\mathrm{Sr}$, if in the Cyrillic, Mongolian =
Mo, Greek = Gr, Georgian = Geor., Japanese $=\mathrm{Ja}$, Chinese $=\mathrm{Ch}$, Arabic $=\mathrm{Ar}$, etc.)

The following order in the reference list is recommended:

Journal articles: Author(s) surname and initials, year. Title. Full title of the journal, volume, pages. Example:

Simm G, Lewis RM, Grundy B and Dingwall WS, 2002. Responses to selection for lean growth in sheep. Animal Science, 74, 39-50

Books: Author(s) surname and initials, year. Title. Edition, name of publisher, place of publication. Example:

Oldenbroek JK, 1999. Genebanks and the conservation of farm animal genetic resources, Second edition. DLO Institute for Animal Science and Health, Netherlands.

Book chapter or conference proceedings: Author(s) surname and initials, year. Title. In: Title of the book or of the proceedings followed by the editor(s), volume, pages. Name of publisher, place of publication. Example:

Mauff G, Pulverer G, Operkuch W, Hummel K and Hidden C, 1995. C3variants and diverse phenotypes of unconverted and converted C3. In: Provides of the Biological Fluids (ed. $\mathrm{H}$. Peters), vol. 22, 143-165, Pergamon Press. Oxford, UK.

Todorov N and Mitev J, 1995. Effect of level of feeding during dry period, and body condition score on reproductive performance in dairy cows, IX $X^{\text {th }}$ International Conference on Production Diseases in Farm Animals, September 11-14, Berlin, Germany.

Thesis:

Hristova D, 2013. Investigation on genetic diversity in local sheep breeds using DNA markers. Thesis for PhD, Trakia University, Stara Zagora, Bulgaria, (Bg).

The Editorial Board of the Journal is not responsible for incorrect quotes of reference sources and the relevant violations of copyrights.

\section{Animal welfare}

Studies performed on experimental animals should be carried out according to internationally recognized guidelines for animal welfare. That should be clearly described in the respective section "Material and methods". 


\section{AGRICULTURAL \\ SCIENCE AND TECHNOLOGY}

Volume 9, Number 4 December 2017
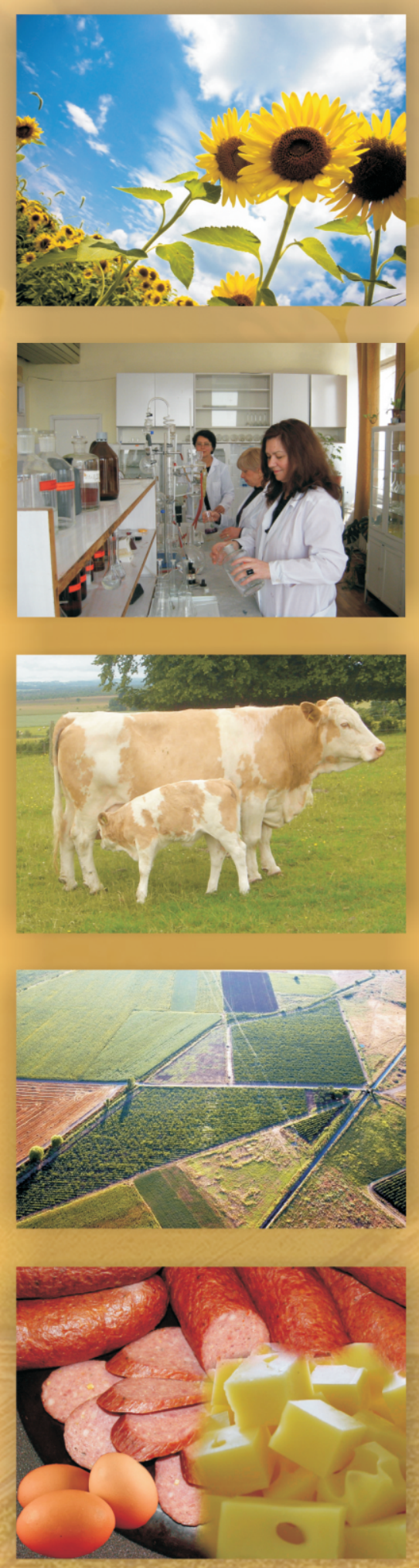

Journal web site: 